\title{
The Responses of Autophagy and Apoptosis to Oxidative Stress in Nucleus Pulposus Cells: Implications for Disc Degeneration
}

\author{
Jiang-Wei Chen Bin-Bin Ni Bo Li Yue-Hua Yang Sheng-Dan Jiang \\ Lei-Sheng Jiang
}

Department of Orthopedic Surgery, Xinhua Hospital, Shanghai Jiaotong University School of Medicine, Shanghai, China

\section{Key Words}

Oxidative stress • Autophagy • Apoptosis • ERK • Nucleus pulposus cells

\begin{abstract}
Background/Aims: Apoptosis and autophagy are two patterns of programmed cell death which play important roles in the intervertebral disc degeneration. Oxidative stress is an important factor for the induction of programmed cell death. However, the cellular reactions linking autophagy to apoptosis of disc cells under oxidative stress have never been described. This study investigated the responses of autophagy and apoptosis and their interactions in the nucleus pulposus cells (NP cells) under oxidative stress, with the aim to better understand the mechanism of disc degeneration. Methods: NP cells isolated from rat lumbar discs were subjected to different concentrations of $\mathrm{H}_{2} \mathrm{O}_{2}$ for various time periods. Cell viability was determined by CCK-8 assay, and their apoptosis and autophagy responses were evaluated by fluorescent analysis, flow cytometry and western blotting, et al. The interactions of autophagy and apoptosis and the possible signaling pathways were also investigated by using autophagy modulators. Results: $\mathrm{H}_{2} \mathrm{O}_{2}$ increased the lysosomal membrane permeability in the NP cells and induced apoptosis through the mitochondrial pathway subsequently. Meanwhile, $\mathrm{H}_{2} \mathrm{O}_{2}$ stimulated an early autophagy response through the ERK/m-TOR signaling pathway. Autophagy inhibition significantly decreased the apoptosis incidence in the cells insulted by $\mathrm{H}_{2} \mathrm{O}_{2}$. Conclusion: These results suggested that controlling the autophagy response in the NP cells under oxidative stress should be beneficial for the survival of the cells and probably delay the process of disc degeneration.
\end{abstract}

JW Chen and BB Ni contributed equally to this paper.

Sheng-Dan Jiang and Lei-Sheng Jiang _ Department of Orthopaedic Surgery, Xinhua Hospital, Shanghai Jiaotong University School of Medicine, No. 1665, Kongjiang Road, Shanghai 200092, (China)

Tel. +86 13002195209, and +86 2125077970

E-Mail jiangsd@126.com and E-Mail jiangleisheng@126.com 


\section{Cellular Physiology and Biochemistry}

Cell Physiol Biochem 2014;34:1175-1189

\begin{tabular}{l|l}
\hline DOI: $10.1159 / 000366330$ & (C) 2014 S. Karger AG, Basel
\end{tabular}

Published online: September 22, 2014

www.karger.com/cpb

\section{Introduction}

Degenerative disc disease is a major cause of neck or back pain in adults, leading to the drop of life quality or even disability. The disease is of widespread prevalence. About $80 \%$ of the adult population would be subjected to neck or back pain at some points in their lives [1]. However, the pathogenesis of intervertebral disc (IVD) degeneration has not been elucidated clearly, although it is acknowledged that programmed cell death (PCD) of IVD cells plays an essential role in this process [2].

Apoptosis, known as type I PCD, is an essential homeostatic mechanism in multicellular organisms, allowing the elimination of no longer needed or seriously damaged cells by an orderly process of cellular disintegration [3]. It is characterized by caspase activation, cell shrinkage, nuclear and cytoplasmic condensation, DNA fragmentation, and formation of apoptosomes [4]. In addition to its importance as a biological phenomenon, excessive apoptosis is also implicated in an extensive variety of diseases [5-7]. Studies have reported that cell loss resulting from apoptosis continues to occur throughout life and plays a vital role in the IVD degenerative progression [8-10].

Autophagy is an evolutionally conserved lysosomal activity to degrade and turn over long-lived proteins and damaged cytoplasmic organelles. Since autophagy was discovered, it has been thought to act as a pro-survival response to several stresses by providing recycled metabolic substrates to maintain energy homeostasis [11]. However, recent studies also suggested that autophagy played a pro-death role in a variety of cell types under different conditions [12-14]. Hyper-induction of autophagy and consequent excessive lysosomal degradation of cell constituents might promote apoptosis or lead to a so-called "autophagic cell death (type II PCD)" [15]. Autophagy has also been reported to be implicated in the progression of disc degeneration [16-19]. The autophagy level in rat NP tissue increased with age and with the degenerative progression of IVD [16, 17].

The relationship between autophagy and apoptosis is complex, as they share the same set of cellular regulator proteins and are closely linked. Autophagy could either inhibit or delay the occurrence of apoptosis [20-25], or promote apoptosis [26, 27]. One of the most important factors involved the control and regulation of apoptosis and autophagy is the cellular redox status [28], which is determined by the balance between the rates of production and breakdown of reactive oxygen species (ROS) [29]. ROS are recognized as very small molecules, such as superoxide anion $\left(\mathrm{O}_{2}^{-{ }^{-}}\right)$, hydroxyl radical $(\mathrm{HO})$ and hydrogen peroxide $\left(\mathrm{H}_{2} \mathrm{O}_{2}\right)$ et al, produced in cell organelles especially in the mitochondria [30]. At physiological level, ROS act as second messengers in various signal transductions [31]. However, elevated ROS could induce autophagy and apoptosis simultaneously or separately due to their high reactivity and damage to proteins, lipids, and DNAs [15, 28, 30, 32, 33]. Recent studies have also reported that oxidative stress was associated with disc degeneration. Over-production of ROS could directly damage the IVD cells and perturb the homeostasis of disc matrix, including reduced proteoglycan synthesis and enhanced expression of matrix metalloproteinases [34-36]. However, the apoptosis and autophagy responses of IVD cells to oxidative stress have never been studied.

In this study, we applied a prototypic $\operatorname{ROS}\left(\mathrm{H}_{2} \mathrm{O}_{2}\right)$ to induce oxidative stress in the nucleus pulposus cells, evaluated the apoptosis and autophagy responses in the cells, and tried to uncover the relationship between autophagy and apoptosis and the possible signaling pathways involved in their interactions. We believe that understanding the autophagy and apoptosis responses of NP cells under oxidative stress is important for better clarifying the mechanism of disc degeneration and should have important clinical significance in the prevention and treatment of degenerative discogenic diseases.

\section{Materials and Methods}

Reagents and antibodies

Cell Counting Kit-8 was from Dojindo (Kyushu, Japan). Annexin V-FITC apoptosis detection kit I was from BD Pharmingen (San Diego, CA, USA). GFP-LC3 and GFP-vector plasmids were kindly provided by Dr. 


\section{Cellular Physiology and Biochemistry}

Cell Physiol Biochem 2014;34:1175-1189

DOI: $10.1159 / 000366330$

Publisned oninne: september 22, 2014

Chen et al.: Disc Cells Under Oxidative Stress (c) 2014 S. Karger AG, Basel

www.karger.com/cpb

Li Wang (Neonatology, Shanghai Jiao Tong University). Lipofectamine-2000 transfection reagent and LysoTracker Red were from Invitrogen (Carlsbad, CA, USA). U0126, SB203580, SP600125, and necrostatin-1 were from Calbiochem (San Diego, CA). All antibodies against relevant antigens, including LC3, p62, Bax, Bcl-2, phospho-ERK1/2, total-ERK1/2, phospho-JNK, total-JNK, phospho-p38 and total-p38 were from Cell Signaling (Beverly, MA). $\mathrm{H}_{2} \mathrm{O}_{2}$ (30\% stock solution) and Bafilomycin A1 were from Sangon Biotech (Shanghai, China). Caspase-3, Caspase-8, and Caspase-9 colorimetric activity assay kit, Hoechst-33258, Z-VAD-FMK were from Beyotime (Nantong, Jiangsu, China). Acridine orange and 3-methyladenine were from SigmaAldrich (St.Louis, MO, USA). The cell culture reagents were from Gibco (Carlsbad, CA, USA).

\section{Cell isolation and culture}

NP cells were isolated from rat lumbar discs using a method previously described by Risbud et al [37]. Briefly, male Sprague-Dawley rats (6 weeks old and 200-250g weight) were euthanized with $\mathrm{CO}_{2}$. The spinal columns were resected en bloc under aseptic condition and lumbar intervertebral discs were collected. The gel-like NP was separated from the annulus fibrosus under a dissection microscope and the tissues were treated with $0.1 \%$ collagenase for 3 hours. The partially digested tissue was maintained as an explant in complete culture medium (DMEM/F12 and 10\% fetal bovine serum (FBS) supplemented with antibiotics) in a humidified atmosphere containing $5 \% \mathrm{CO}_{2}$ at $37^{\circ} \mathrm{C}$. NP cells migrated out of the explant after 1 week. When confluent, the primary-passage cells were harvested using $0.25 \%$ trypsin-EDTA (1mM) solution and replanted into appropriate culture plates. Second-passage cells maintained in a monolayer were used throughout the experiments. All experimental procedures were approved by the Animal Care and Use Committee of our university, conformed to the institutional guidelines.

\section{Cell viability assay}

The viability of NP cells was determined by Cell Counting Kit-8 (CCK-8) assays according to the manufacturer's instructions. Cells $\left(1 \times 10^{4}\right.$ cells/well $)$ were seeded in 96 -well flat-bottomed plates and incubated in $100 \mu \mathrm{l}$ of complete culture medium. Different concentrations of $\mathrm{H}_{2} \mathrm{O}_{2}$ were added to the medium and incubated for various times. Each treatment was repeated in five wells. As soon as the treatments were completed, $10 \mu \mathrm{l}$ solution from CCK- 8 was added to $100 \mu \mathrm{l}$ culture media each well. These plates were continuously incubated for 2 hours in a humidified $\mathrm{CO}_{2}$ incubator at $37^{\circ} \mathrm{C}$. Finally, the absorbance of the sample taken from each well was measured on an automicroplate reader (Bio-Rad, Hercules, CA, USA) at $450 \mathrm{~nm}$. Cell viability was expressed as percentage of viable cells relative to untreated cells, using absorbance at $450 \mathrm{~nm}$.

\section{Apoptosis incidence detection by flow cytometry}

Apoptosis incidence was detected by using the Annexin V-FITC apoptosis detection kit. Cells were grown in 60-mm culture dishes until $90 \%$ confluence. Then they were treated with $\mathrm{H}_{2} \mathrm{O}_{2}$ for the time indicated. After treatments, the attached cells that remained were harvested $(0.25 \%$ trypsin $)$ and pooled with any floating (detached) cells. The cells were then collected by centrifugation (5minutes, 1000rpm) and re-suspended in $1 \mathrm{X}$ Binding Buffer at a concentration of $1 \times 10^{6}$ cells $/ \mathrm{ml}$. $100 \mathrm{ul}$ of the solution $\left(1 \times 10^{5}\right.$ cells) was transfered to a $5 \mathrm{ml}$ culture tube. $5 \mu \mathrm{l}$ of Annexin V-FITC and $5 \mu \mathrm{l}$ of PI were added into the tube. The cells were gently vortexed and incubated for $15 \mathrm{~min}$ at room temperature $\left(25^{\circ} \mathrm{C}\right)$ in the dark. Then $400 \mu \mathrm{l}$ of $1 \mathrm{X}$ Binding Buffer was added into each tube, and flow cytometry analysis was performed within one hour. The apoptotic rate was calculated by the percentage of early apoptotic (Annexin V+/PI-) cells plus the percentage of late apoptotic (Annexin $\mathrm{V}+\mathrm{PI}+$ ) cells.

\section{Morphologic detection of the apoptotic cells}

NP cells were prepared at a density of 50,000 cells per well in a 24-well plate. After treatments, the cells were fixed with $4 \%$ paraformaldehyde for 15 minutes, washed with PBS for three times and stained with $2 \mu \mathrm{g} / \mathrm{ml}$ Hoechst 33258 solution for 5 minutes. Morphologic changes in apoptotic nuclei were evaluated under the fluorescence microscope (Olympus Fluoview, Tokyo, Japan). A percentage was calculated by the strong blue staining cells/total cells ratio $\times 100 \%$ in five random fields. Hoechst 33258 staining discriminates apoptotic cells from normal ones by showing brightly fluorescent DNA fragmentation and chromatin condensation under fluorescence microscopy. 


\section{Cellular Physiology and Biochemistry}

Cell Physiol Biochem 2014;34:1175-1189

DOI: $10.1159 / 000366330$

ublisnea onine: september 22, 2014

(C) 2014 S. Karger AG, Basel

www.karger.com/cpb

Caspase-3, Caspase-8, and Caspase-9 activity detection

The activities of caspase- $3,-8$, and -9 were detected separately by using colorimetric activity assay kits. According to the instructions, cell samples were incubated in a lysis buffer containing $1 \%$ Dithiothreitol (DTT) on ice for $15 \mathrm{~min}$ and then centrifuged at 20,000 rpm for $15 \mathrm{~min}$ to isolate proteins. The protein concentration was determined using Bradford protein assay. $200 \mu \mathrm{g}$ protein lysate from each sample was incubated with $5 \mu \mathrm{L}$ of caspase-3, or -8 , or -9 substrate and $1 \%$ DTT in 96-well plates separately in $100 \mu \mathrm{L}$ of reaction buffer at $37^{\circ} \mathrm{C}$, avoiding light for $4 \mathrm{~h}$. The activities of caspase- $-3,-8$, and -9 were evaluated using a spectrophotometer at $405 \mathrm{~nm}$.

Mitochondrial membrane potential measurement

The value of mitochondrial membrane potential $(\mathrm{mt} \Delta \psi)$ was determined by the dual-emission potential-sensitive probe, JC-1 staining, according to the manufacturer's instructions. Briefly, after treatment with $\mathrm{H}_{2} \mathrm{O}_{2}$ for the time indicated, the NP cells were harvested and re-suspended in a mixture of $500 \mu \mathrm{L}$ culture medium and $500 \mu \mathrm{L} \mathrm{JC}-1$ staining fluid, and then incubated in the dark at $37^{\circ} \mathrm{C}$ for $20 \mathrm{~min}$. After washing with ice-cold staining buffer twice and centrifugation, cells were re-suspended in $500 \mu \mathrm{L}$ culture medium and analyzed by flow cytometry. In cells with normal mitochondria having a high $\mathrm{mt} \Delta \psi$, JC- 1 formed orange-red fluorescent J-aggregates, while in cells with depolarized or damaged mitochondria, the sensor dye appeared as green fluorescent monomers. The value of $m t \Delta \psi$ from each sample was expressed as the ratio of red fluorescence intensity over green fluorescence intensity.

GFP-LC3 plasmid transfection and autophagy assay

NP cells were incubated at a density of $2 \times 10^{5}$ on 12 -well plates and cultured up to $60 \%$ confluence. GFPLC3 transfection was carried out with Lipofectamine 2000 according to the manufacturer's recommendation. $2 \mathrm{mg} / \mathrm{ml}$ GFP-LC3 or GFP-vector plasmid DNA in each dish was used. After incubation in Opti-MEM medium for 6 hours, the cells were incubated in complete culture medium again for 24 hours. Then the transfected cells were treated with $\mathrm{H}_{2} \mathrm{O}_{2}$ for the indicated time. Finally, the cells were fixed with $4 \%$ paraformaldehyde, and then washed twice in cold PBS. Autophagy was evaluated by analyzing the formation of fluorescent puncta of autophagosomes in GFP-LC3 transfected cells under the fluorescent microscope.

\section{Western blotting analysis}

Cell samples were lysed in RIPA buffer, sonicated, and protein concentrations were calculated by BCA protein assay kit. The extracted proteins were resolved on $12 \%$ sodium dodecyl sulfate-polyacrylamide gels and transferred by electroblotting to polivinyledene fluoride (PVDF) membranes (Bio-Rad, Her-cules, CA). The membranes were blocked with blocking solution for 2 hours and then incubated overnight at $4^{\circ} \mathrm{C}$ with the primary antibodies to LC3, p62, Bax, Bcl-2, phospho-mTOR, Total-mTOR, phospho-p70S6K, Totalp70S6K, phospho-ERK1/2, Total-ERK1/2, phospho-JNK, Total-JNK, phospho-p38 and Total-p38. After being washed with Tris Buffered Saline with Tween (TBST) for three times, the membranes were incubated with the respective secondary antibodies. Then the bands were detected with ECL plus reagent (Millipore) by the ChemiDoc ${ }^{\mathrm{TM}} \mathrm{XRS}+$ System (BIO-RAD, USA). Relative expression levels of proteins were determined by quantitative densitometric analysis using image analysis software (Image lab, BIO-RAD, USA).

\section{Lysosome membrane permeability detection}

Integrity of lysosomal membrane was assayed in living cells by the acridine orange (AO) retention test and by Lyso-tracker Red staining as described elsewhere [38]. Briefly, after $\mathrm{H}_{2} \mathrm{O}_{2}$ treatment, cells were incubated with $75 \mathrm{nM}$ Lyso-Tracker Red or $0.5 \mu \mathrm{g} / \mathrm{ml}$ AO for $15 \mathrm{~min}$ at $37^{\circ} \mathrm{C}$ under appropriate growth conditions and then observed under a fluorescence microscope. Fluorescence intensity was measured by using image analysis software (ImagePro, Media Cybernetics, Silver Springs, o Maryland). Lyso-Tracker Red target to acidic membranous structures, especially lysosomes, and emit red fluorescence in the cytoplasm. The red fluorescence would weaken if lysosome membrane permeability (LMP) increased. AO is a cellpermeable lysosomotropic agent that fluoresces when excited with blue light. Acid compartments stained with AO fluoresces red when retained within lysosomes and green when it localizes in the cytosol.

\section{Statistical analysis}

Data were presented as means \pm SD (standard deviation) for at least three independent experiments. Statistical analyses were carried out using the SPSS 15 statistical software program (SPSS, Inc., Chicago, IL). 


\begin{tabular}{rl|l} 
Cellular Physiology & Cell Physiol Biochem 2014;34:1175-1189 \\
\cline { 2 - 3 } and Biochemistry & $\begin{array}{l}\text { DOI: 10.1159/000366330 } \\
\text { Publisned onine: September 22, 2014 }\end{array}$ & $\begin{array}{l}\text { O 2014 S. Karger AG, Basel } \\
\text { www.karger.com/cpb }\end{array}$ \\
\cline { 2 - 3 } Chen et al.: Disc Cells Under Oxidative Stress &
\end{tabular}

Fig. 1. $\mathrm{H}_{2} \mathrm{O}_{2}$ induced apoptotic cell death in NP cells. (A) CCK-8 assay for the cell viability. NP cells were treated with different concentrations of $\mathrm{H}_{2} \mathrm{O}_{2}$ for 24 hours or with $400 \mu \mathrm{M}$ $\mathrm{H}_{2} \mathrm{O}_{2}$ for different time periods. (B) Colorimetric activity assay for caspase-3, -8, and -9. NP cells were treated with $400 \mu \mathrm{M}$ $\mathrm{H}_{2} \mathrm{O}_{2}$ for 24 hours, with or without Z-VAD-FMK preincubation for 1 hour. (C) CCK-8 assay for the cell viability. Z-VAD-FMK or necrostatin-1 was pre-incubated for 1 hour before the treatment of $400 \mu \mathrm{M} \mathrm{H}_{2} \mathrm{O}_{2}$ for 24 hours. (D) Hoechst 33258 staining for apoptotic cells. NP cells were incuba-

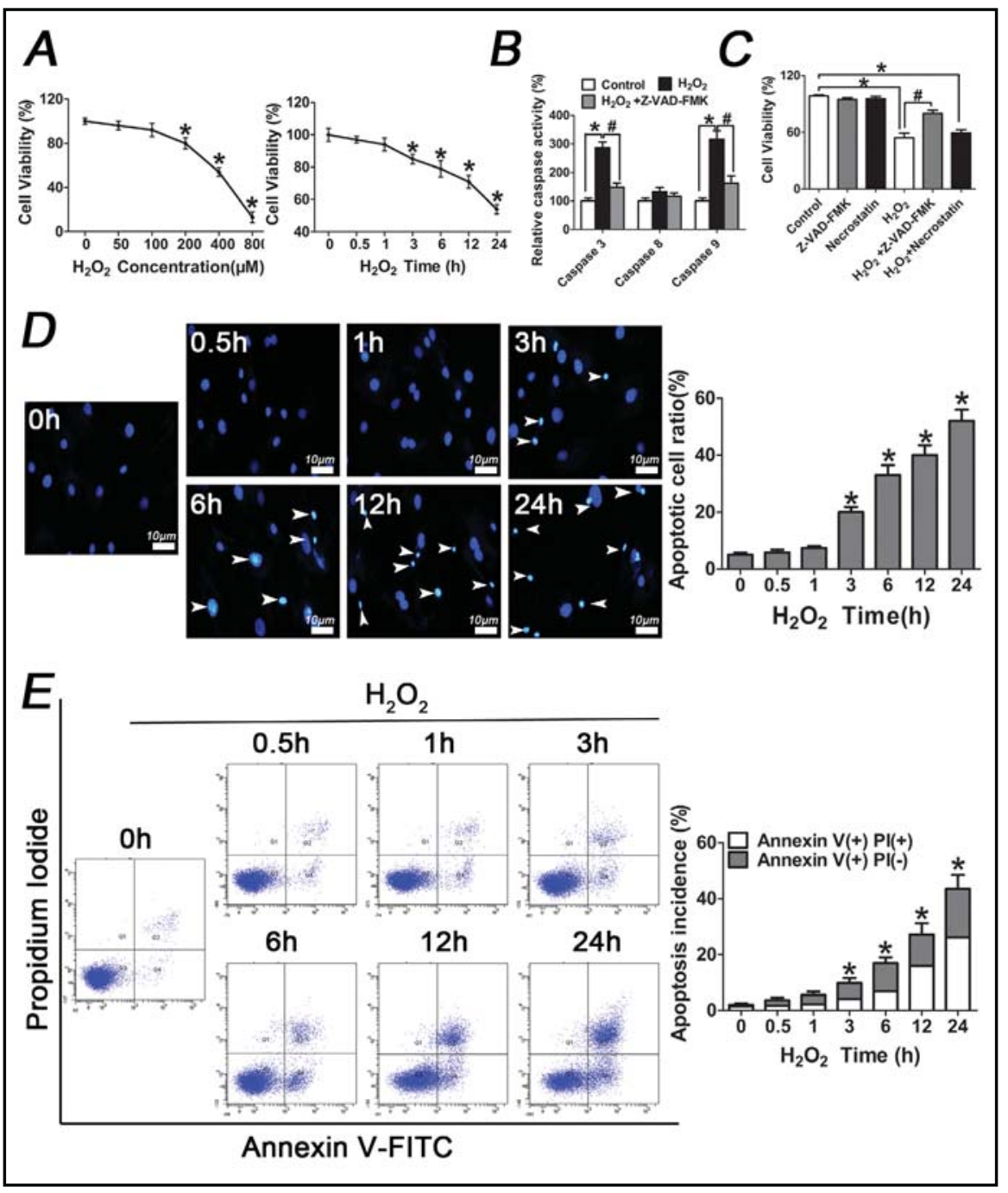
ted with $400 \mu \mathrm{M} \mathrm{H}_{2} \mathrm{O}_{2}$ for different time periods. (E) Flow cytometric analysis for apoptosis incidence. NP cells were incubated with $400 \mu \mathrm{M} \mathrm{H}_{2} \mathrm{O}_{2}$ for different time periods. The apoptosis incidence was calculated by the percentage of early apoptotic (Annexin V+/PI-) cells plus the percentage of late apoptotic (Annexin $\mathrm{V}+$ / $\mathrm{PI}+$ ) cells. Data were presented as mean \pm SD from three independent experiments. The cells without $\mathrm{H}_{2} \mathrm{O}_{2}$ treatment were served as control. ${ }^{*} \mathrm{P}<0.05$ versus control, \# $\mathrm{P}<0.05$.

Multiple comparison of data among the groups were determined by the one-way ANOVA followed by the least significant difference test (Fisher test) and the significance was evaluated by the unpaired Student's test for comparisons between two means. Differences were considered statistically significant when $P<$ 0.05 .

\section{Results}

$\mathrm{H}_{2} \mathrm{O}_{2}$ induced apoptotic cell death in NP cells

First, we evaluated the cytotoxicity of $\mathrm{H}_{2} \mathrm{O}_{2}$ to NP cells. CCK-8 assay showed that the viable cells reduced to $96 \%, 92 \%, 80 \%, 54 \%$ and $13 \%$ separately, when second-passage NP cells were incubated in a 96-well plate and exposed with different concentrations of $\mathrm{H}_{2} \mathrm{O}_{2}$ (50,100, 200, 400 and $800 \mu \mathrm{M}$ ) for 24 hours (Fig. 1A). As $400 \mu \mathrm{M}$ of $\mathrm{H}_{2} \mathrm{O}_{2}$ had a definite cytotoxicity, we used this concentration in all next experiments. When the NP cells were 
Fig. 2. $\mathrm{H}_{2} \mathrm{O}_{2}$ increased the lysosome membrane permeability and induced apoptosis through the mitochondrial pathway in NP cells. (A) Lyso-tracker red and Acridine orange (AO) staining for the lysosome membrane permeability (LMP). NP cells were treated with $400 \mu \mathrm{M} \quad \mathrm{H}_{2} \mathrm{O}_{2}$ for 1 hour. (B) Mitochondria membrane potential $(\mathrm{mt} \Delta \psi)$ analyzed by flow cytometry through JC-1 staining. $\mathrm{NP}$ cells were treated with $400 \mu \mathrm{M} \mathrm{H} \mathrm{H}_{2} \mathrm{O}_{2}$ for different time periods. The quantitative $\mathrm{mt} \Delta \psi$ from each sample was expressed as the ratio of red fluorescence intensity over the green fluorescence intensity. (C) Western blotting analysis for the protein expressions of Cytochrome c, Bax and Bcl-2. NP cells were treated with $400 \mu \mathrm{M} \mathrm{H}_{2} \mathrm{O}_{2}$ for different time periods. The ratio of Bax/Bcl-2 was quantified. Data were presented as mean \pm SD from three independent experiments. The cells without $\mathrm{H}_{2} \mathrm{O}_{2}$ treatment were served as control.

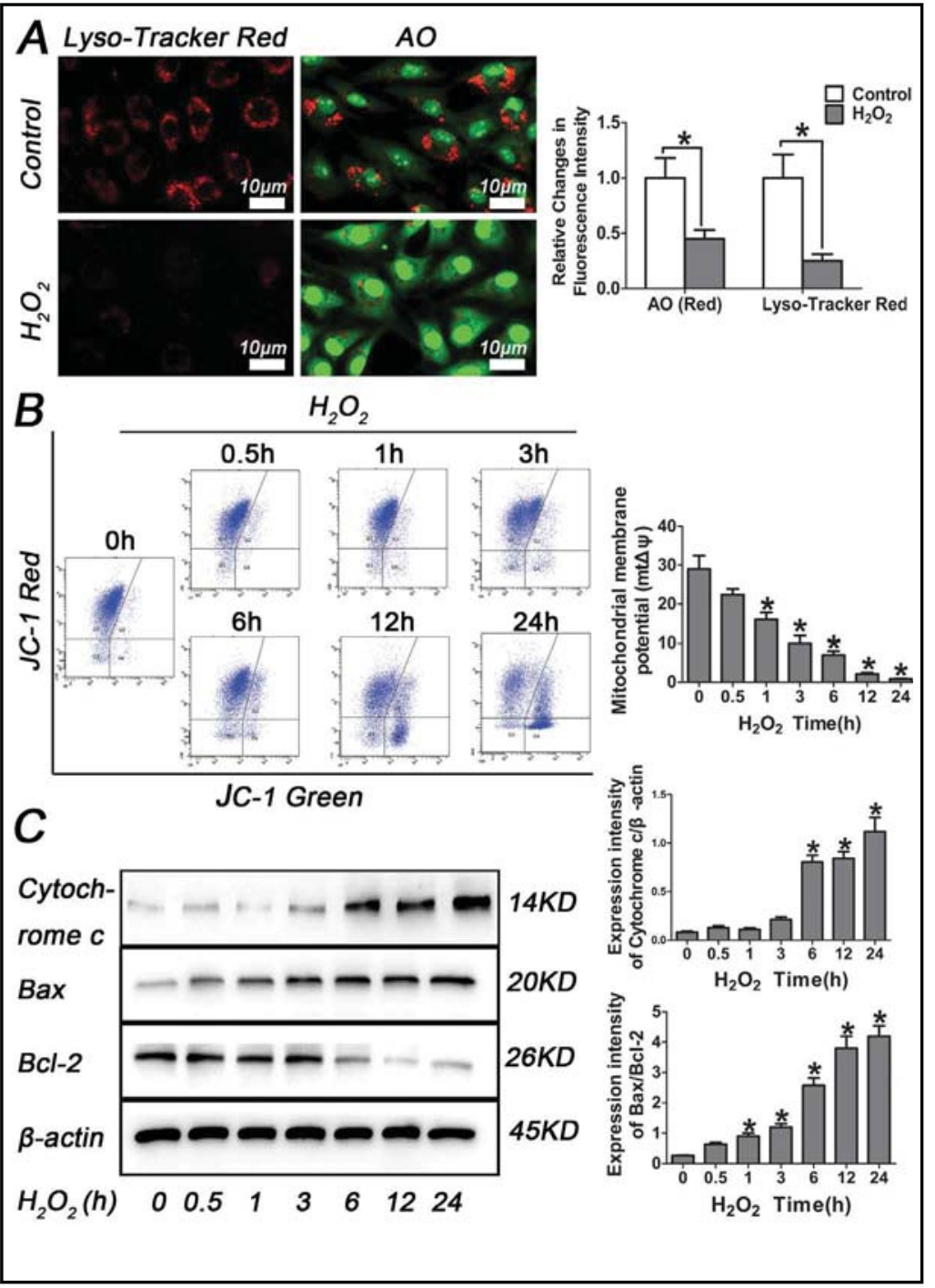
$* \mathrm{P}<0.05$.

exposed to $400 \mu \mathrm{M} \mathrm{H}_{2} \mathrm{O}_{2}$ for different time periods $(0.5,1,3,6,12,24 \mathrm{~h})$, their viability was reduced to $97 \%, 94 \%, 85 \%, 79 \%, 71 \%$, and $54 \%$ separately (Fig. 1A). These results indicated that $\mathrm{H}_{2} \mathrm{O}_{2}$ could definitely cause death of the NP cells and this cytotoxicity was dependent on its dose and acting time.

Next, we evaluated the apoptosis response of the NP cells under oxidative stress. Colorimetric assay revealed that the activities of caspase- 3 , caspase- 8 and caspase- 9 in NP cells increased to $287 \%, 132 \%$ and $316 \%$ separately, when NP cells were treated with $400 \mu \mathrm{M} \mathrm{H}_{2} \mathrm{O}_{2}$ for $24 \mathrm{~h}$. Z-VAD-FMK $(20 \mu \mathrm{M}$, a pan-caspase inhibitor) significantly inhibited the boosted activities of both caspase-3 and caspase-9 in the NP cells (Fig. 1B), along with the increase of cell viability from $54 \%$ to $81 \%$ (Fig. 1C). Meanwhile, necrostatin- 1 ( $30 \mu \mathrm{M}$, the necrosis inhibitor) had no obvious effect on $\mathrm{H}_{2} \mathrm{O}_{2}$-induced cell death (Fig. 1C). Apoptosis morphological evaluation by Hoechst 33258 staining showed that more apoptotic cells with high bright fluorescence were observed after $\mathrm{H}_{2} \mathrm{O}_{2}$ treatment (Fig. 1D). Flow cytometric analysis by using Annexin V-FITC/PI stainning showed that the number of apoptotic cells with surface-associated annexin- $V$ staining (early apoptosis plus late apoptosis) gradually increased with the prolonged time of $\mathrm{H}_{2} \mathrm{O}_{2}$ treatment (Fig. 1E). These results indicated that $\mathrm{H}_{2} \mathrm{O}_{2}$ induced apoptotic cell death (not necrosis) in NP cells. 
Fig. 3. $\mathrm{H}_{2} \mathrm{O}_{2}$ induced autophagy in NP cells. (A) Fluorescent microscopy for the formation and distribution of GFP-LC3 punctate. GFPLC3 or GFP-vector plasmid transfected NP cells were incubated in $400 \mathrm{uM} \mathrm{H}_{2} \mathrm{O}_{2}$ for different time periods. The transfected cells without $\mathrm{H}_{2} \mathrm{O}_{2}$ treatment were served as control. (B) Western blotting for the protein levels of LC3-II and p-62. NP cells were incubated in $400 \mathrm{uM}$ $\mathrm{H}_{2} \mathrm{O}_{2}$ for different time periods. The cells without $\mathrm{H}_{2} \mathrm{O}_{2}$ treatment were served as control. (C) Autophagic flux determination. Bafilomycin A1 (BAF, 100nM) was pre-incubated for 1 hour in the NP cells before $\mathrm{H}_{2} \mathrm{O}_{2}(400 \mu \mathrm{M})$ treatment for another 1 hour. Data were presented as mean \pm SD from three independent experiments. * $\mathrm{P}<0.05$, \# $\mathrm{P}<0.05$.

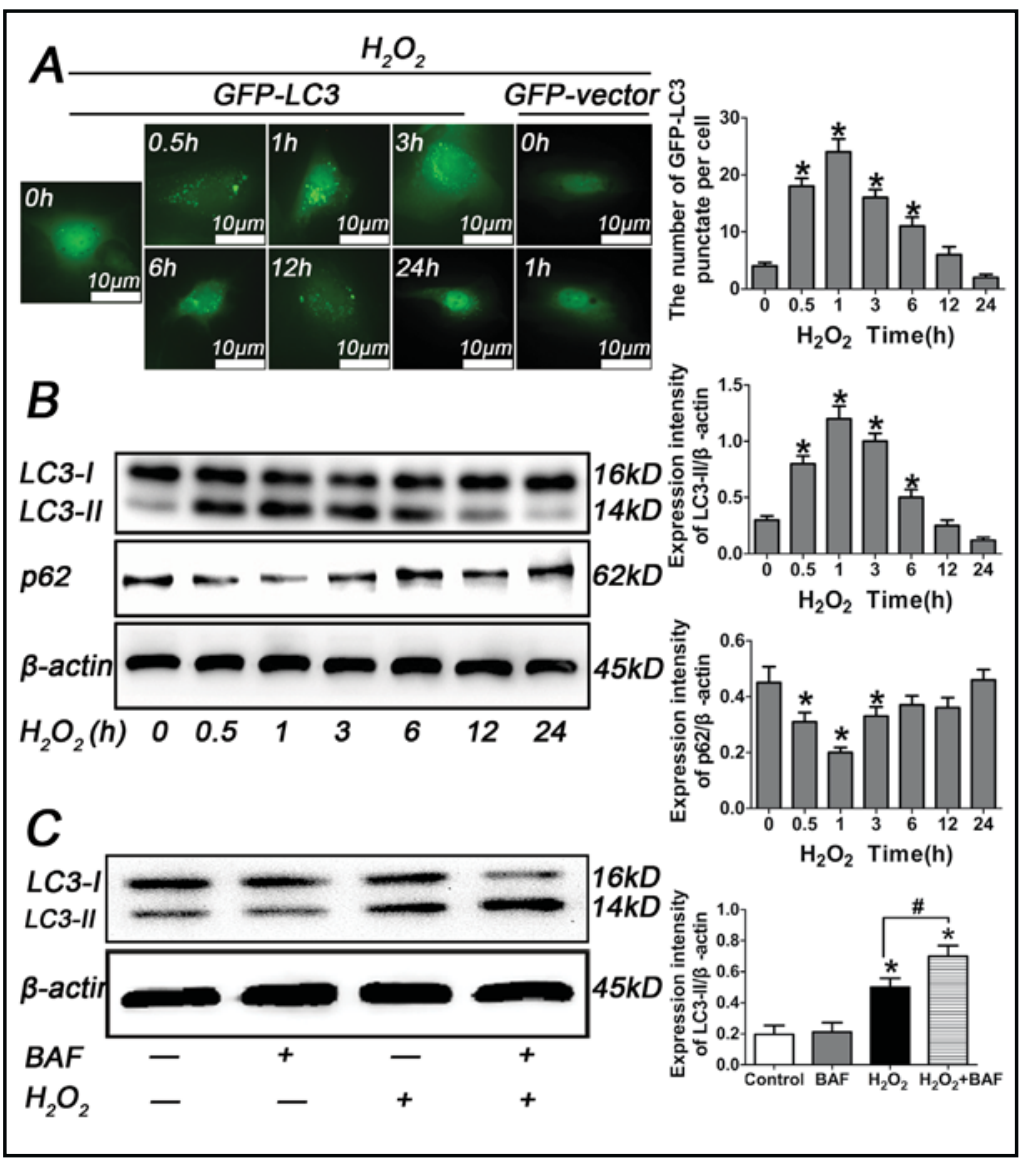

$\mathrm{H}_{2} \mathrm{O}_{2}$ increased lysosome membrane permeability and induced apoptosis through the mitochondrial pathway in NP cells

It has been reported that oxidative stress could induce cell apoptosis through increasing the lysosome membrane permeability (LMP) [38]. NP cells were exposed to $400 \mu \mathrm{M} \mathrm{H}_{2} \mathrm{O}_{2}$ for 1 hour and stained with Lyso-Tracker Red or AO separately. The $\mathrm{H}_{2} \mathrm{O}_{2}$-treated cells exhibited an obviously weakened Lyso-Tracker red fluorescence. An increase in green fluorescence with a reciprocal decrease in red flurorescence was also observed in the cells stained with AO upon exposure to $\mathrm{H}_{2} \mathrm{O}_{2}$ (Fig. 2A). These results indicated that $\mathrm{H}_{2} \mathrm{O}_{2}$ increased the LMP in NP cells.

Since we had found that $\mathrm{H}_{2} \mathrm{O}_{2}$ significantly increased the activities of caspase- 3 and caspase-9 (Fig. 1B), we speculated that the mitochondrial pathway should be involved in the apoptosis of the NP cells under oxidative stress. NP cells were treated with $400 \mathrm{uM} \mathrm{H}_{2} \mathrm{O}_{2}$ for different time periods $(0.5,1,3,6,12,24 \mathrm{~h})$ and the mitochondrial membrane potential $(\mathrm{mt} \Delta \psi$ ) was measured with the specific mitochondrial dye JC-1. Flow cytometry analysis for JC-1 staining revealed that the relative ratio of red fluorescence intensity / green fluorescence intensity in the NP cells decreased with the acting time of $\mathrm{H}_{2} \mathrm{O}_{2}$, in a manner corresponding to that of apoptosis incidence (Fig. 2B). In addition, western blotting analysis showed that $\mathrm{H}_{2} \mathrm{O}_{2}$ increased the release of cytoplasm cytochrome $\mathrm{c}$, which is another mitochondrial event during apoptosis. The ratio of pro-apoptotic protein Bax/anti-apoptotic protein Bcl-2 was also increased in the NP cells with the acting time of $\mathrm{H}_{2} \mathrm{O}_{2}$, representing the dispersal of mitochondrial membrane potential, hence the mitochondria mediated apoptosis (Fig. 2C). All these results verified that the mitochondrial pathway was involved in the $\mathrm{H}_{2} \mathrm{O}_{2}$ induced apoptosis of NP cells. 


\begin{tabular}{ll|l} 
Cellular Physiology & Cell Physiol Biochem 2014;34:1175-1189 \\
and Biochemistry & $\begin{array}{l}\text { DOI: 10.1159/000366330 } \\
\text { Publisned onine: September 22, 2014 }\end{array}$ & $\begin{array}{l}\text { O 2014 S. Karger AG, Basel } \\
\text { www.karger.com/cpb }\end{array}$ \\
\cline { 2 - 3 } Chen et al.: Disc Cells Under Oxidative Stress &
\end{tabular}

Fig. 4. $\mathrm{H}_{2} \mathrm{O}_{2}$ induced autophagy in NP cells through the ERK signaling pathway. (A) Western blotting for the protein levels of MAPKs (ERK, JNK, p-38). NP cells were exposed to $400 \mathrm{uM} \mathrm{H}_{2} \mathrm{O}_{2}$ for different time periods. The cells without $\mathrm{H}_{2} \mathrm{O}_{2}$ treatment were served as control. (B) Western blotting for the protein levels of MAPKs (ERK, JNK, p-38) and LC3-II/I. NP cells were pre-treated or not with the respective inhibitors for 1 hour in the presence or absence of $400 \mu \mathrm{M} \mathrm{H}_{2} \mathrm{O}_{2}$ for 1 hour. (C) Western blotting for the protein levels of mTOR and p70S6K. NP cells were treated with $400 \mu \mathrm{M} \mathrm{H}_{2} \mathrm{O}_{2}$ for different time periods. The cells without $\mathrm{H}_{2} \mathrm{O}_{2}$ treatment were served as control. Data were presented as mean \pm SD from three independent experiments. $* \mathrm{P}<0.05$.

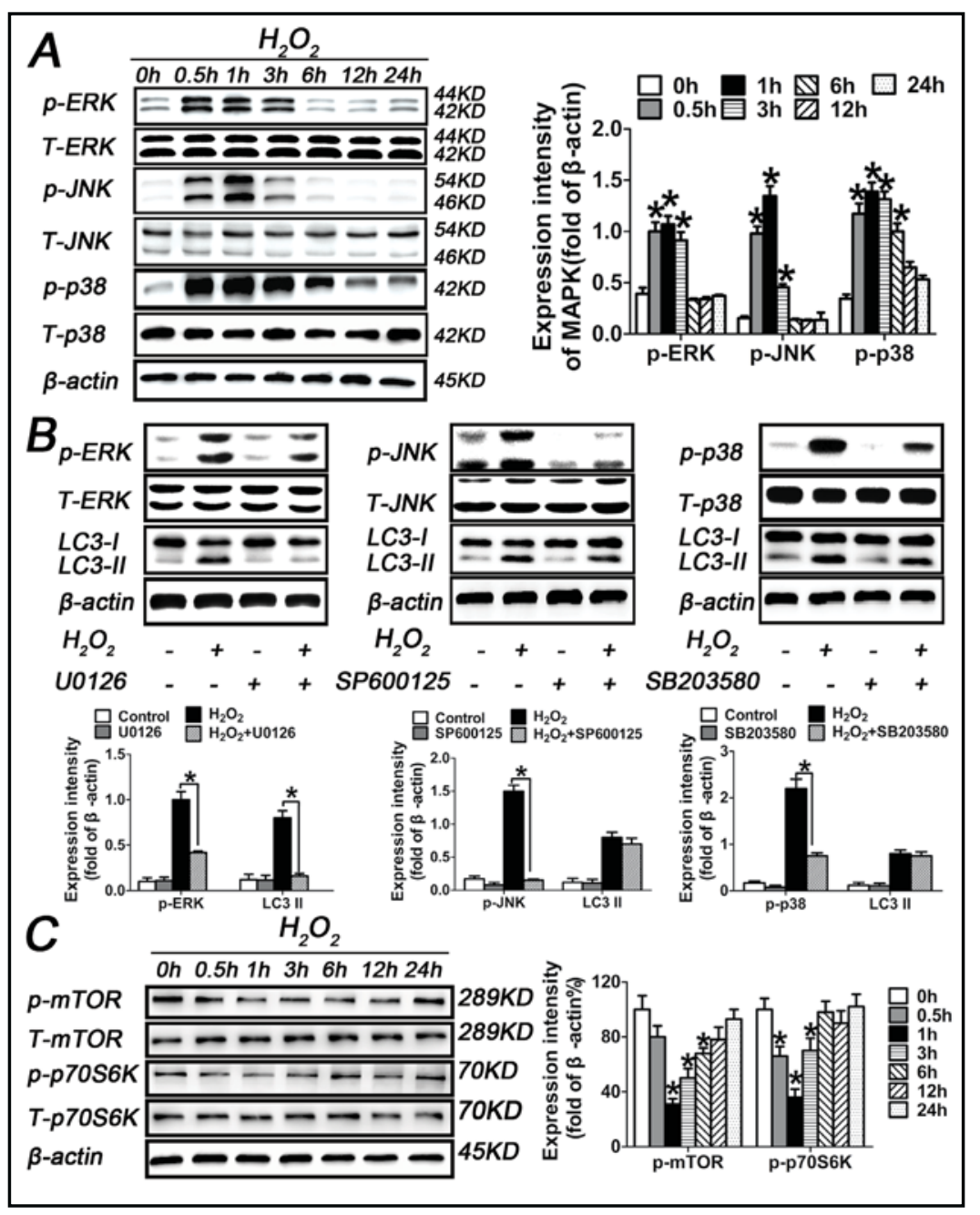

$\mathrm{H}_{2} \mathrm{O}_{2}$ induced autophagy in the NP cells

Autophagy starts with the emergence of a double-membrane crescent that matures to a sealed double-membrane vesicle, called autophagosome, which subsequently fuses with lysosome, leading to degradation of the contents. In order to investigate whether autophagy was present in the NP cells stimulated by $\mathrm{H}_{2} \mathrm{O}_{2}$, we detected the formation of autophagosomes by monitoring the subcellular localization of fluorescent chimeric protein GFP-LC3, an acknowledged method to evaluate autophagy previously described by Klionsky, et al [39]. Successful GFP-LC3 transfection was verified in the NP cells by demonstrating the green fluorescence under fluorescent microscopy. The transfected cells were then treated with $400 \mathrm{uM} \mathrm{H}_{2} \mathrm{O}_{2}$ for various time periods $(0.5,1,3,6,12,24 \mathrm{~h})$. Under fluorescent microscopy, the cells showed a punctate green fluorescence, indicating the vacuolar localization of LC3. The proportion of punctate green fluorescence in the cytoplasm increased immediately after $\mathrm{H}_{2} \mathrm{O}_{2}$ incubation, peaked at 1 hour and then gradually declined. However, punctate green fluorescence could not be observed in GFP-vector cells treated with or without $\mathrm{H}_{2} \mathrm{O}_{2}$ (Fig. $3 \mathrm{~A})$. These results proved the presence of autophagy in the NP cells shortly after stimulation by $\mathrm{H}_{2} \mathrm{O}_{2}$.

Next, we measured the proteins levels of LC3 and p62 (markers of autophagy) in the NP cells. LC3 is the mammalian equivalent of yeast Atg8 and has two subtypes: LC3-I and LC3-II. Autophagosome formation is associated with the conversion of cytosolic-associated protein light chain 3 (LC3-I) into the membrane-bound LC3-II form Thus, detection of LC3-II can be used to estimate the abundance of autophagosomes. P62 is a substrate of autophagy which 
Fig. 5. The interactions between apoptosis and autophagy in NP cells under oxidative stress. NP cells were pre-treated for 1 hour with 3-methyladenine (3MA, $5 \mathrm{mM}$ ), or bafilomycin A1 (BAF 100nM) or U0126 $(20 \mu \mathrm{M})$ and then stimulated with $400 \mu \mathrm{M} \mathrm{H}_{2} \mathrm{O}_{2}$ for 3 and 24 hours. (A) Western blotting analysis. (B) Apoptosis incidence quantified by flow cytometry through Annexin V-FITC and PI staining. (C) The mitochondria membrane potential $(\mathrm{mt} \Delta \psi)$ measured by flow cytometry through JC-1 staining. Data were presented as mean \pm SD from three independent experiments. The cells pre-treated with vehicle were served as control. $* \mathrm{P}<0.05$.

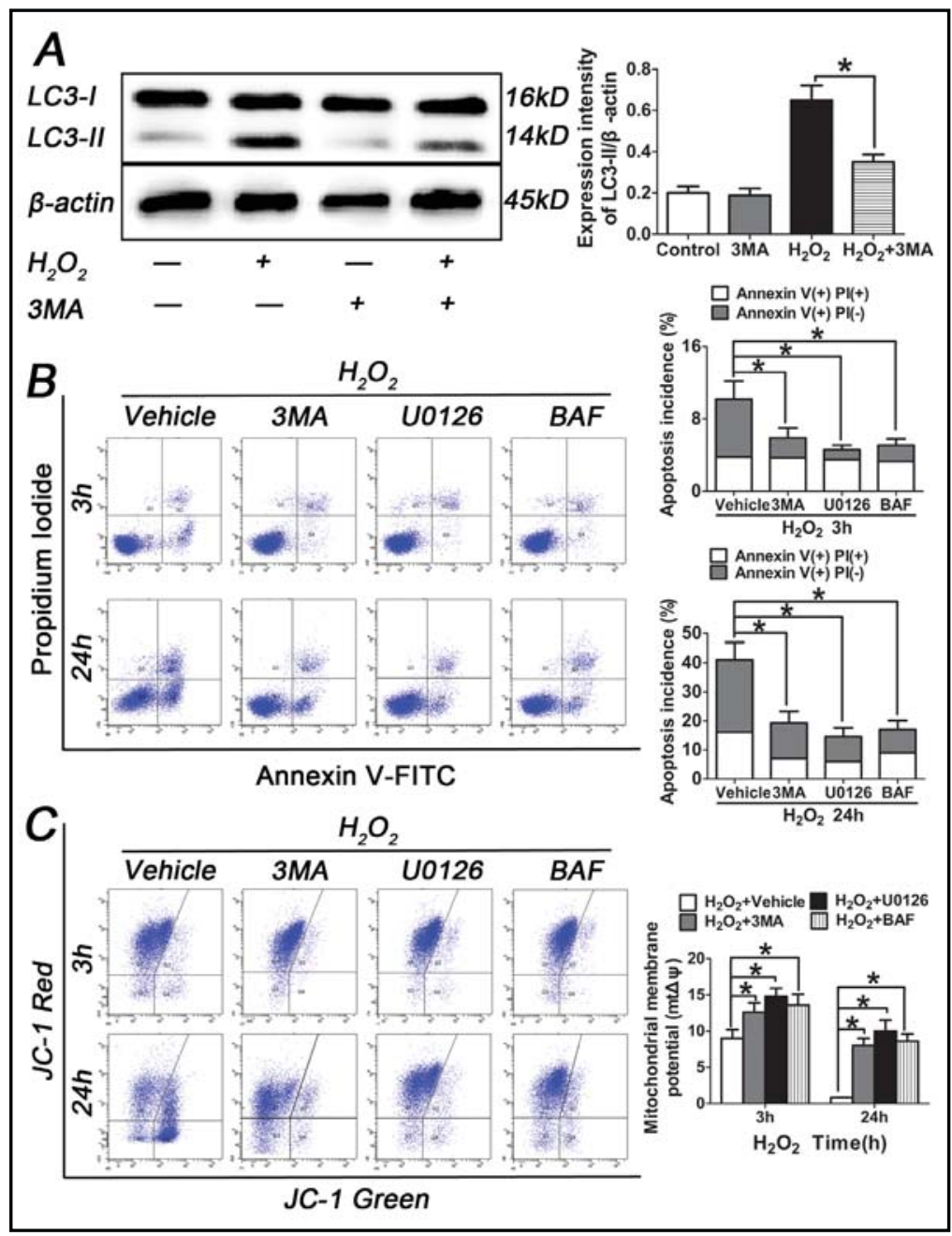

can be degraded by autolysosomes. Autophagy deficiency can lead to the accumulation of p62 [40]. Western blotting analysis showed that the protein conversion of LC3-I to LC3-II immediately increased when the NP cells were insulted by $400 \mathrm{uM} \mathrm{H}_{2} \mathrm{O}_{2}$ for 0.5 hour, reached to the highest level at 1 hour and then dropped down gradually. Accordingly, the protein expression of p62 was the least at 1 hour upon $\mathrm{H}_{2} \mathrm{O}_{2}$ treatment (Fig. 3B).

However, autophagosome accumulation and increased LC3-II levels could be resulted from true increased autophagic flux or from its defective fusion with lysosomes. To further analyze the role of $\mathrm{H}_{2} \mathrm{O}_{2}$ in the induction of autophagy, the LC3-II levels were analyzed during $\mathrm{H}_{2} \mathrm{O}_{2}$ exposure in the presence of bafilomycin A1 (BAF, 100nM), a well-known inhibitor of autophagosomal lysosome degradation. Western blotting analysis showed that BAF further accumulated the $\mathrm{H}_{2} \mathrm{O}_{2}$-induced LC3-II in NP cells, indicating that $\mathrm{H}_{2} \mathrm{O}_{2}$-mediated conversion of LC3-II was due to an increase of autophagic flux (Fig. 3C).

All the evidences supported that $\mathrm{H}_{2} \mathrm{O}_{2}$ stimulated an early autophagy response in the NP cells.

\section{$\mathrm{H}_{2} \mathrm{O}_{2}$ induced autophagy in NP cells through the ERK signaling pathway}

Mitogen-activated protein kinases (MAPKs) are the family of kinases that transduce signals from the cell membrane to the nucleus in response to a wide range of stimuli, including oxidative stress $[41,42]$. So we investigated whether the MAPKs system was involved in the autophagy induced by $\mathrm{H}_{2} \mathrm{O}_{2}$ in NP cells. Western blotting analysis for the NP cells showed that the phosphorylation of all the three MAPK family members, including extracellular signalregulated kinase 1/2 (ERK1/2), c-Jun N-terminalkinase (JNK) and p38 MAPK, immediately 


\section{Cellular Physiology and Biochemistry}

Cell Physiol Biochem 2014;34:1175-1189

\begin{tabular}{l|l}
\hline DOI: $10.1159 / 000366330$ & C 2014 S. Karger AG, Basel
\end{tabular}

Chen et al.: Disc Cells Under Oxidative Stress

increased after $400 \mathrm{uM} \mathrm{H} \mathrm{H}_{2} \mathrm{O}_{2}$ exposure for 0.5 hour, reached to the highest level at 1 hour and then dropped down gradually (Fig. 4A). $\mathrm{H}_{2} \mathrm{O}_{2}$ activated multiple members of MAPK in NP cells, in a manner corresponding to that of autophagy.

Next, the respective role of ERK1/2, JNK and p38 activation in $\mathrm{H}_{2} \mathrm{O}_{2}$-induced NP cell autophagy was investigated by using their relevant inhibitors. The ERK inhibitor U0126 $(20 \mu \mathrm{M})$, JNK inhibitor SP600125 $(20 \mu \mathrm{M})$ and p38 inhibitor SB203580 $(10 \mu \mathrm{M})$ all efficiently blocked the activation of corresponding MAPKs. However, only U0126 significantly attenuated $\mathrm{H}_{2} \mathrm{O}_{2}$-induced LC3-II protein accumulation, SP600125 and SB203580 had little effect on the expression of LC3-II (Fig. 4B). These results suggested that $\mathrm{H}_{2} \mathrm{O}_{2}$ induced autophagy mainly through ERK signaling pathway.

Mammalian target of rapamycin (mTOR) is the down-stream kinase of ERK, and inhibition of its phosphorylation (p-mTOR) is regarded as a key step in triggering autophagy. Western blotting analysis showed that the protein expression of p-mTOR was suppressed in the $\mathrm{H}_{2} \mathrm{O}_{2}$ treated NP cells, in a manner corresponding to that of the autophagy. Similar changes were also found in the phosphorylation level of p70S6K at Thr389, which is a downstream effector of mTOR signaling (Fig. 4C).

All these evidence proved that $\mathrm{H}_{2} \mathrm{O}_{2}$ induced autophagy in NP cells through the activation of the ERK/m-TOR signaling pathway.

The relationship between apoptosis and autophagy in NP cells under oxidative stress

The crosstalk between autophagy and apoptosis is complicated, and varies in different cell types and different stimuli [43]. We found that autophagy in the NP cells activated and peaked within a very short time after $\mathrm{H}_{2} \mathrm{O}_{2}$ treatment (Fig. 3A\&B), quite earlier than apoptosis (Fig. 1D\&E). To investigate the interplay between autophagy and apoptosis in the NP cells under oxidative stress, cells were pre-treated with 3 -methyladenine (3MA, $5 \mathrm{mM}$, an autophagy inhibitor), or BAF (100nM) or U0126 $(20 \mu \mathrm{M})$ for 1 hour before $\mathrm{H}_{2} \mathrm{O}_{2}$ exposure. Western blotting analysis showed the conversion of LC3-I to LC3-II in $\mathrm{H}_{2} \mathrm{O}_{2}$-treated cells was significantly attenuated in the presence of 3MA (Fig. 5A). BAF pretreatment successfully disrupted the autophagic flux (Fig. 3C), and U0126 (Fig. 4B) inhibited the autophagy induction. Meanwhile, both the relative early stage (3h) and late stage $(24 \mathrm{~h})$ apoptosis incidence decreased significantly when early autophagy was inhibited in the $\mathrm{H}_{2} \mathrm{O}_{2}$-treated NP cells (Fig. 5B), along with simultaneous increases in the mt $\Delta \psi$ (Fig. 5C). These results suggested that autophagy was a preceding event for apoptosis in the NP cells insulted by $\mathrm{H}_{2} \mathrm{O}_{2}$ and that suppression of early autophagy could down-regulate the mitochondrial-mediated apoptosis in the NP cells under oxidative stress.

\section{Discussion}

The main findings of the present study were that $\mathrm{H}_{2} \mathrm{O}_{2}$ induced autophagy through the ERK/m-TOR signaling pathway and apoptosis through the mitochondrial pathway in the NP cells. Autophagy occurred quite earlier than apoptosis. Suppression of autophagy could down-regulate the mitochondrial-mediated apoptosis in the NP cells under oxidative stress.

Oxidative stress could lead to multiple types of cell damage, including DNA breaks, protein oxidation and carbonylation, lipid per-oxidation, mitochondrial failure, alterations of calcium homeostasis, actin reorganization, NAD depletion, impairment of the energy metabolism, and glutathione depletion [44]. It was recognized as an important cellular stress with significant pathological implications in many disease processes [45]. There were reports that $\mathrm{H}_{2} \mathrm{O}_{2}$ induced cartilage destruction in vivo through increasing apoptosis of chondrocytes, and resulted in osteoarthritis ultimately $[46,47]$. There were also reports that $\mathrm{H}_{2} \mathrm{O}_{2}$ led to dysfunction and increased apoptosis of osteoblasts, thus contributed to the development of osteonecrosis $[41,48]$. Although residing in a hypoxic environment and getting energy mainly through glycolysis, NP cells still generated ROS through oxidative metabolism, especially in aged or degenerated discs with neovascularization [34, 49]. The 


\section{Cellular Physiology and Biochemistry}

Cell Physiol Biochem 2014;34:1175-1189

\begin{tabular}{l|l}
\hline DOI: $10.1159 / 000366330$ & (C) 2014 S. Karger AG, Basel
\end{tabular}

www.karger.com/cpb

Chen et al.: Disc Cells Under Oxidative Stress

pro-inflammatory cytokines further stimulated the production of ROS in NP cells [34]. Thus, we believed that the increased apoptosis of NP cells under oxidative stress should be involved in the pathogenesis of IVD degeneration.

Mitochondria are the major source and target of ROS [50]. When the formation of ROS is enhanced, it would impair the function of mitochondria, such as respiration and oxidative phosphorylation, mitochondrial permeability transition [51]. Then the mitochondria can commit cells to apoptosis by releasing cytochrome c, Smac/Diablo, AIF and activating procaspase- 9 and $-3[52,53]$. There were reports that ROS mediated mitochondria-dependent apoptosis in various types of cells [31, 52, 54]. Singh et al. [54] and Luo et al. [52] reported that hydrogen peroxide induced apoptosis by mitochondrial death pathway in HeLa cells and rat Schwann's cells respectively. Our study also demonstrated that $\mathrm{H}_{2} \mathrm{O}_{2}$ induced the downregulation of $\mathrm{mt} \Delta \psi$ and the release of cytochrome $\mathrm{c}$ to cytosol, indicating the mitochondria pathway was involved in the apoptosis in the NP cells under oxidative stress. In addition, we also observed increased LMP in the NP cells after $\mathrm{H}_{2} \mathrm{O}_{2}$ stimulation. Lysosomes contain more than 50 acidic hydrolases, which take part in the degradation of all cellular elements. The mechanism of apoptosis induction by oxidative stress had been attributed to LMP in several studies, by releasing lysosomal enzymes into the cytosol, activating caspases and other toxic cascades [38,45,54]. Takahashi et al. [46] reported that lysosomal dysfunction with swelling and rupture was closely associated with the ROS formation that occurred after the addition of $\mathrm{H}_{2} \mathrm{O}_{2}$ to osteoarthritic chondrocytes at the early period of apoptosis. Thus, we suggested that maintaining the integrity of lysosome and normal function of mitochondria might be crucial for the survival of NP cells. Meanwhile, recent studies reported that ROS could be produced not only in the mitochondria [55-57]. Roberto Mangiullo et al. [55] confirmed the presence of a functionally active ecto-FoF1-ATP synthase (a mitochondrial inner membranebound enzyme) on the plasma membrane of normal tissue cells. Isabella Panfoli et al. [57] confirmed the extra-mitochondrial tricarboxylic acid cycle in retinal rod outer segments. As a consequence, we speculated that the abnormal oxidative stress might also affect the viability of NP cells by influencing the full play of extra-mitochondrial aerobic metabolism.

Autophagy and apoptosis shared the same set of cellular regulatory proteins, and they could be induced by the same stimuli [58]. Cellular oxidative stress was recognized as an important stimulus to autophagy in many studies [59,60]. Zhang et al. [30] reported that hydrogen peroxide indicated oxidative stress induced parallel autophagy and apoptosis in human glioma U251 Cells. Kong et al. [61] reported that Calyxin Y induces hydrogen peroxide-dependent autophagy in human non-small cell lung cancer NCI-H460 cells. Hence, our demonstration that autophagy in NP cells was induced by $\mathrm{H}_{2} \mathrm{O}_{2}$ might not be surprising.

However, the interplay between autophagy and apoptosis is complex and controversial, depending on the types of cells and stresses [43]. Autophagy could either inhibit or delay the occurrence of apoptosis, or promote apoptosis, or induce autophagic cell death independent of apoptosis [62]. Wu et al. [63] indicated that autophagy prevented cells in starvation from undergoing apoptosis in Spodoptera litura SL-ZSU-1 cells. Wang et al. [64] stated that YM155, a novel survivin suppressant, induced autophagy-dependent apoptosis in prostate cancer cells, and inhibition of either early or late events of autophagy attenuated YM155-induced apoptosis. Chen et al. [33] reported that oxidative stress induced autophagic cell death independent of apoptosis in transformed and cancer cells. In our present study, inhibition of autophagy by 3MA, BAF or U0126 separately reduced the apoptosis incidence in the NP cells under oxidative stress, suggesting that autophagy was a necessary preceding event for apoptosis in the NP cells insulted by $\mathrm{H}_{2} \mathrm{O}_{2}$. This result was in accordance with the recent work by Lee et al. [65] who showed that astrocytic death induced by $\mathrm{H}_{2} \mathrm{O}_{2}$ was accompanied by increased LMP and that autophagy inhibitors (3MA, BAF) attenuated the disruption of LMP and cell death in astrocytes. Castino et al. [15] also showed that down-regulation of autophagy via 3MA-mediated inhibition of PI3k III prevented apoptosis and necrosis by oxidative stress in dopaminergic neuroblastoma cells. Thus, we suggested that control and regulation of autophagy activity might be an effective strategy to reduce the apoptosis of NP cells under oxidative stress and to prevent the degeneration of IVD. 


\section{Cellular Physiology and Biochemistry}

Cell Physiol Biochem 2014;34:1175-1189

\begin{tabular}{l|l}
\hline DOI: $10.1159 / 000366330$ & (C) 2014 S. Karger AG, Basel
\end{tabular}

Chen et al.: Disc Cells Under Oxidative Stress

Furthermore, our present study indicated that $\mathrm{H}_{2} \mathrm{O}_{2}$ induced autophagy in NP cells through the ERK/m-TOR signaling pathway. ERK is a widely conserved family of serine/ threonine protein kinases implicated in many cellular programs such as cell proliferation, differentiation, and apoptosis [66]. It can be activated by a wide variety of oncogenes and extra-cellular stimuli including mitogens, growth factors, cytokines and ROS [67]. An increasing number of studies have suggested that ERK is implicated in the regulation of autophagy. Sivaprasad et al. [68] indicated that inhibition of ERK in MCF-7 cells resulted in decreased autophagy in response to TNF. Wong et al. [28] reported that ROS-dependent ERK induced non-canonical autophagy in cancer cells. As the down-stream kinase of ERK, the inhibition of p-mTOR has consistently been associated with induction of autophagy [69]. Our results showed that $\mathrm{H}_{2} \mathrm{O}_{2}$ treatment inactivated mTOR and reduced phosphorylation of its downstream target p70S6K, corresponding to the variation of autophagy. These findings indicated that $\mathrm{H}_{2} \mathrm{O}_{2}$ induced autophagy through mTOR-dependent mechanisms in NP cells. Thus, ERK/m-TOR signaling pathway might be a target to control the autophagy and apoptosis level in the NP cells under oxidative stress.

\section{Conclusions}

Our study revealed that $\mathrm{H}_{2} \mathrm{O}_{2}$ induced autophagy through the ERK/m-TOR signaling pathway and apoptosis through the mitochondrial pathway in the NP cells. Inhibition of ERK-dependent autophagy reduced the mitochondria-mediated apoptosis in the NP cells under oxidative stress. These data should be helpful to improve our understanding of the cell death mechanism of NP cells under oxidative stress, and the intricate relationship between autophagy and apoptosis. Modulating the autophagy in the disc cells under oxidative stress might be a new therapeutic direction to reduce the apoptosis of the cells and prevent IVD degeneration.

\section{Acknowledgments}

This work is supported by the National Natural Science Foundation of China (No 81000793, 81171757) and fund from Shanghai Health Bureau (XYQ2011026).

\section{Disclosure Statement}

The authors declare no conflict of interests.

\section{References}

1 Feng G, Li L, Liu H, Song Y, Huang F, Tu C, Shen B, Gong Q Li T, Liu L, Zeng J, Kong Q Yi M, Gupte M, Ma PX, Pei F: Hypoxia differentially regulates human nucleus pulposus and annulus fibrosus cell extracellular matrix production in 3d scaffolds. Osteoarthritis Cartilage 2013;21:582-588.

2 Zhao CQ, Jiang LS, Dai LY: Programmed cell death in intervertebral disc degeneration. Apoptosis 2006;11:2079-2088.

3 Ben-juan W, Zeng-tong Z: Hydrogen peroxide induced apoptosis in sv-40 transformed human salivary gland acinar cells. Oral Oncol 2007;43:248-251.

4 Kunchithapautham K, Rohrer B: Apoptosis and autophagy in photoreceptors exposed to oxidative stress. Autophagy 2007;3:433-441.

5 Zhao CQ, Zhang YH, Jiang SD, Jiang LS, Dai LY: Both endoplasmic reticulum and mitochondria are involved in disc cell apoptosis and intervertebral disc degeneration in rats. Age (Dordr) 2010;32:161-177.

-6 Lisse TS, Thiele F, Fuchs H, Hans W, Przemeck GK, Abe K, Rathkolb B, Quintanilla-Martinez L, Hoelzlwimmer G, Helfrich M, Wolf E, Ralston SH, Hrabe de Angelis M: Er stress-mediated apoptosis in a new mouse model of osteogenesis imperfecta. PLoS Genet. 2008;4:e7. 


\section{Cellular Physiology and Biochemistry}

Cell Physiol Biochem 2014;34:1175-1189

\begin{tabular}{l|l}
\hline DOI: $10.1159 / 000366330$ & (C) 2014 S. Karger AG, Basel
\end{tabular}

Chen et al.: Disc Cells Under Oxidative Stress

7 Han S, Liang CP, DeVries-Seimon T, Ranalletta M, Welch CL, Collins-Fletcher K, Accili D, Tabas I, Tall AR: Macrophage insulin receptor deficiency increases er stress-induced apoptosis and necrotic core formation in advanced atherosclerotic lesions. Cell Metab 2006;3:257-266.

-8 Ding F, Shao ZW, Xiong LM: Cell death in intervertebral disc degeneration. Apoptosis 2013;18:777-785.

9 Zhang L, Niu T, Yang SY, Lu Z, Chen B: The occurrence and regional distribution of dr4 on herniated disc cells: A potential apoptosis pathway in lumbar intervertebral disc. Spine (Phila Pa 1976) 2008;33:422-427.

10 Gruber HE, Hanley EN, Jr.: Analysis of aging and degeneration of the human intervertebral disc. Comparison of surgical specimens with normal controls. Spine (Phila Pa 1976) 1998;23:751-757.

11 Kang C, Avery L: To be or not to be, the level of autophagy is the question: Dual roles of autophagy in the survival response to starvation. Autophagy 2008;4:82-84.

12 Cui D, Wang L, Qi A, Zhou Q, Zhang X, Jiang W: Propofol prevents autophagic cell death following oxygen and glucose deprivation in pc12 cells and cerebral ischemia-reperfusion injury in rats. PloS One 2012;7:e35324.

13 Koike M, Shibata M, Tadakoshi M, Gotoh K, Komatsu M, Waguri S, Kawahara N, Kuida K, Nagata S, Kominami E, Tanaka K, Uchiyama Y: Inhibition of autophagy prevents hippocampal pyramidal neuron death after hypoxic-ischemic injury. Am J Pathol 2008;172:454-469.

14 Wang ZQ, Yang Y, Lu T, Luo P, Li J, Wu JP, Tang ZZ, Lu QP, Duan QH: Protective effect of autophagy inhibition on ischemia-reperfusioninduced injury of n2a cells. J Huazhong Univ Sci Technology Med Sci 2013;33:810816.

15 Castino R, Bellio N, Follo C, Murphy D, Isidoro C: Inhibition of pi3k class iii-dependent autophagy prevents apoptosis and necrosis by oxidative stress in dopaminergic neuroblastoma cells. Toxicol Sci 2010;117:152162.

16 Ye W, Xu K, Huang D, Liang A, Peng Y, Zhu W, Li C: Age-related increases of macroautophagy and chaperonemediated autophagy in rat nucleus pulposus. Connect Tissue Res 2011;52:472-478.

17 Ye W, Zhu W, Xu K, Liang A, Peng Y, Huang D, Li C: Increased macroautophagy in the pathological process of intervertebral disc degeneration in rats. Connect Tissue Res 2013;54:22-28.

18 Jiang L, Zhang X, Zheng X, Ru A, Ni X, Wu Y, Tian N, Huang Y, Xue E, Wang X, Xu H: Apoptosis, senescence, and autophagy in rat nucleus pulposus cells: Implications for diabetic intervertebral disc degeneration. J Orthop Res 2013;31:692-702.

19 Shen C, Yan J, Jiang LS, Dai LY: Autophagy in rat annulus fibrosus cells: Evidence and possible implications. Arthritis Res Ther 2011;13:R132.

20 Moreau K, Luo S, Rubinsztein DC: Cytoprotective roles for autophagy. Curr Opin Cell Biol. 2010;22:206-211.

$\longrightarrow 21$ Ding Y, Kim JK, Kim SI, Na HJ, Jun SY, Lee SJ, Choi ME: Tgf-\{beta\}1 protects against mesangial cell apoptosis via induction of autophagy. J Biol Chem 2010;285:37909-37919.

-22 Ravikumar B, Berger Z, Vacher C, O'Kane CJ, Rubinsztein DC: Rapamycin pre-treatment protects against apoptosis. Hum Mol Genet 2006;15:1209-1216.

23 Fiorini C, Menegazzi M, Padroni C, Dando I, Dalla Pozza E, Gregorelli A, Costanzo C, Palmieri M, Donadelli M: Autophagy induced by p53-reactivating molecules protects pancreatic cancer cells from apoptosis. Apoptosis. 2013;18:337-346. 24 Carames B, Taniguchi N, Otsuki S, Blanco FJ, Lotz M: Autophagy is a protective mechanism in normal cartilage, and its aging-related loss is linked with cell death and osteoarthritis. Arthritis Rheum 2010;62:791-801.

25 Dodson M, Liang Q, Johnson MS, Redmann M, Fineberg N, Darley-Usmar VM, Zhang J: Inhibition of glycolysis attenuates 4-hydroxynonenal-dependent autophagy and exacerbates apoptosis in differentiated sh-sy5y neuroblastoma cells. Autophagy 2013;9:1996-2008.

26 Wu W, Zhang X, Hu X, Wang X, Sun L, Zheng X, Jiang L, Ni X, Xu C, Tian N, Zhu S, Xu H: Lactate downregulates matrix systhesis and promotes apoptosis and autophagy in rat nucleus pulposus cells. J Orthop Res 2014;32:253-261.

-27 Chang KH, Yan MD, Yao CJ, Lin PC, Lai GM: Honokiol-induced apoptosis and autophagy in glioblastoma multiforme cells. Oncol Lett. 2013;6:1435-1438. 28 Wong CH, Iskandar KB, Yadav SK, Hirpara JL, Loh T, Pervaiz S: Simultaneous induction of non-canonical autophagy and apoptosis in cancer cells by rosdependent erk and jnk activation. PloS One 2010;5:e9996.

29 Orrenius S: Reactive oxygen species in mitochondria-mediated cell death. Drug Metab Rev 2007;39:443455.

-30 Zhang H, Kong X, Kang J, Su J, Li Y, Zhong J, Sun L: Oxidative stress induces parallel autophagy and mitochondria dysfunction in human glioma u251 cells. Toxicol Sci 2009;110:376-388. 


\section{Cellular Physiology and Biochemistry}

Cell Physiol Biochem 2014;34:1175-1189

Published online: September 22, 2014

(C) 2014 S. Karger AG, Basel

www.karger.com/cpb

31 Wei H, Li Z, Hu S, Chen X, Cong X: Apoptosis of mesenchymal stem cells induced by hydrogen peroxide concerns both endoplasmic reticulum stress and mitochondrial death pathway through regulation of caspases, p38 and jnk. J Cell Biochem 2010;111:967-978.

32 Lu JM, Lin PH, Yao Q, Chen C: Chemical and molecular mechanisms of antioxidants: Experimental approaches and model systems. J Cell Mol Med 2010;14:840-860.

-33 Chen Y, McMillan-Ward E, Kong J, Israels SJ, Gibson SB: Oxidative stress induces autophagic cell death independent of apoptosis in transformed and cancer cells. Cell Death Differ 2008;15:171-182.

-34 Nasto LA, Robinson AR, Ngo K, Clauson CL, Dong Q St Croix C, Sowa G, Pola E, Robbins PD, Kang J, Niedernhofer LJ, Wipf P, Vo NV: Mitochondrial-derived reactive oxygen species (ros) play a causal role in aging-related intervertebral disc degeneration. J Orthop Res 2013;31:1150-1157.

35 Vo N, Niedernhofer LJ, Nasto LA, Jacobs L, Robbins PD, Kang J, Evans CH: An overview of underlying causes and animal models for the study of age-related degenerative disorders of the spine and synovial joints. J Orthop Res 2013;31:831-837.

-36 Cheng YH, Yang SH, Lin FH: Thermosensitive chitosan-gelatin-glycerol phosphate hydrogel as a controlled release system of ferulic acid for nucleus pulposus regeneration. Biomaterials 2011;32:6953-6961.

-37 Risbud MV, Fertala J, Vresilovic EJ, Albert TJ, Shapiro IM: Nucleus pulposus cells upregulate pi3k/akt and mek/erk signaling pathways under hypoxic conditions and resist apoptosis induced by serum withdrawal. Spine (Phila Pa 1976) 2005;30:882-889.

-38 Castino R, Bellio N, Nicotra G, Follo C, Trincheri NF, Isidoro C: Cathepsin d-bax death pathway in oxidative stressed neuroblastoma cells. Free Radic Biol Med 2007;42:1305-1316.

-39 Klionsky DJ, Abeliovich H, Agostinis P, Agrawal DK, Aliev G, Askew DS, Baba M, Baehrecke EH, Bahr BA, Ballabio A, Bamber BA, Bassham DC, Bergamini E, Bi X, Biard-Piechaczyk M, Blum JS, Bredesen DE, Brodsky JL, Brumell JH, Brunk UT, Bursch W, Camougrand N, Cebollero E, Cecconi F, Chen Y, Chin LS, Choi A, Chu CT, Chung J, Clarke PG, Clark RS, Clarke SG, Clave C, Cleveland JL, Codogno P, Colombo MI, Coto-Montes A, Cregg JM, Cuervo AM, Debnath J, Demarchi F, Dennis PB, Dennis PA, Deretic V, Devenish RJ, Di Sano F, Dice JF, Difiglia M, Dinesh-Kumar S, Distelhorst CW, Djavaheri-Mergny M, Dorsey FC, Droge W, Dron M, Dunn WA, Jr., Duszenko M, Eissa NT, Elazar Z, Esclatine A, Eskelinen EL, Fesus L, Finley KD, Fuentes JM, Fueyo J, Fujisaki K, Galliot B, Gao FB, Gewirtz DA, Gibson SB, Gohla A, Goldberg AL, Gonzalez R, Gonzalez-Estevez C, Gorski S, Gottlieb RA, Haussinger D, He YW, Heidenreich K, Hill JA, Hoyer-Hansen M, Hu X, Huang WP, Iwasaki A, Jaattela M, Jackson WT, Jiang X, Jin S, Johansen T, Jung JU, Kadowaki M, Kang C, Kelekar A, Kessel DH, Kiel JA, Kim HP, Kimchi A, Kinsella TJ, Kiselyov K, Kitamoto K, Knecht E, Komatsu M, Kominami E, Kondo S, Kovacs AL, Kroemer G, Kuan CY, Kumar R, Kundu M, Landry J, Laporte M, Le W, Lei HY, Lenardo MJ, Levine B, Lieberman A, Lim KL, Lin FC, Liou W, Liu LF, Lopez-Berestein G, Lopez-Otin C, Lu B, Macleod KF, Malorni W, Martinet W, Matsuoka K, Mautner J, Meijer AJ, Melendez A, Michels P, Miotto G, Mistiaen WP, Mizushima N, Mograbi B, Monastyrska I, Moore MN, Moreira PI, Moriyasu Y, Motyl T, Munz C, Murphy LO, Naqvi NI, Neufeld TP, Nishino I, Nixon RA, Noda T, Nurnberg B, Ogawa M, Oleinick NL, Olsen LJ, Ozpolat B, Paglin S, Palmer GE, Papassideri I, Parkes M, Perlmutter DH, Perry G, Piacentini M, Pinkas-Kramarski R, Prescott M, Proikas-Cezanne T, Raben N, Rami A, Reggiori F, Rohrer B, Rubinsztein DC, Ryan KM, Sadoshima J, Sakagami H, Sakai Y, Sandri M, Sasakawa C, Sass M, Schneider C, Seglen PO, Seleverstov O, Settleman J, Shacka JJ, Shapiro IM, Sibirny A, Silva-Zacarin EC, Simon HU, Simone C, Simonsen A, Smith MA, SpanelBorowski K, Srinivas V, Steeves M, Stenmark H, Stromhaug PE, Subauste CS, Sugimoto S, Sulzer D, Suzuki T, Swanson MS, Tabas I, Takeshita F, Talbot NJ, Talloczy Z, Tanaka K, Tanaka K, Tanida I, Taylor GS, Taylor JP, Terman A, Tettamanti G, Thompson CB, Thumm M, Tolkovsky AM, Tooze SA, Truant R, Tumanovska LV, Uchiyama Y, Ueno T, Uzcategui NL, van der Klei I, Vaquero EC, Vellai T, Vogel MW, Wang HG, Webster P, Wiley JW, Xi Z, Xiao G, Yahalom J, Yang JM, Yap G, Yin XM, Yoshimori T, Yu L, Yue Z, Yuzaki M, Zabirnyk O, Zheng X, Zhu X, Deter RL: Guidelines for the use and interpretation of assays for monitoring autophagy in higher eukaryotes. Autophagy 2008;4:151-175.

40 Yang Z, Klionsky DJ: An overview of the molecular mechanism of autophagy. Curr Top Microbiol Immunol 2009;335:1-32.

41 She C, Zhu LQ, Zhen YF, Wang XD, Dong QR: Activation of ampk protects against hydrogen peroxideinduced osteoblast apoptosis through autophagy induction and nadph maintenance: New implications for osteonecrosis treatment? Cell Signal 2014;26:1-8.

-42 Lee J, Giordano S, Zhang J: Autophagy, mitochondria and oxidative stress: Cross-talk and redox signalling. Biochem J. 2012;441:523-540.

43 Levine B, Yuan J: Autophagy in cell death: An innocent convict? J Clin Invest. 2005;115:2679-2688.

-44 Cerella C, Coppola S, Maresca V, De Nicola M, Radogna F, Ghibelli L: Multiple mechanisms for hydrogen peroxide-induced apoptosis. Ann N Y Acad Sci 2009;1171:559-563. 


\section{Cellular Physiology and Biochemistry}

Cell Physiol Biochem 2014;34:1175-1189

\begin{tabular}{l|l}
\hline DOI: $10.1159 / 000366330$ & (C) 2014 S. Karger AG, Basel
\end{tabular}

Chen et al.: Disc Cells Under Oxidative Stress

-45 Essick EE, Sam F: Oxidative stress and autophagy in cardiac disease, neurological disorders, aging and cancer. Oxid Med Cell Longev 2010;3:168-177.

46 Takahashi T, Kitaoka K, Ogawa Y, Kobayashi T, Seguchi H, Tani T, Yoshida S: Lysosomal dysfunction on hydrogen peroxide-induced apoptosis of osteoarthritic chondrocytes. Int J Mol Med 2004;14:197-200.

47 Lo MY, Kim HT: Chondrocyte apoptosis induced by hydrogen peroxide requires caspase activation but not mitochondrial pore transition. J Orthop Res 2004;22:1120-1125.

48 Liang D, Xiang L, Yang M, Zhang X, Guo B, Chen Y, Yang L, Cao J: Znt7 can protect mc3t3-e1 cells from oxidative stress-induced apoptosis via pi3k/akt and mapk/erk signaling pathways. Cell Signal 2013;25:1126-1135.

49 Agrawal A, Guttapalli A, Narayan S, Albert TJ, Shapiro IM, Risbud MV: Normoxic stabilization of hif-1alpha drives glycolytic metabolism and regulates aggrecan gene expression in nucleus pulposus cells of the rat intervertebral disk. Am J Physiol Cell Physiol 2007;293:C621-631.

50 Xu Y, Ruan S, Wu X, Chen H, Zheng K, Fu B: Autophagy and apoptosis in tubular cells following unilateral ureteral obstruction are associated with mitochondrial oxidative stress. Int J Mol Med 2013;31:628-636.

51 Ding F, Shao ZW, Yang SH, Wu Q, Gao F, Xiong LM: Role of mitochondrial pathway in compression-induced apoptosis of nucleus pulposus cells. Apoptosis 2012;17:579-590.

52 Luo X, Chen B, Zheng R, Lin P, Li J, Chen H: Hydrogen peroxide induces apoptosis through the mitochondrial pathway in rat schwann cells. Neurosci Lett 2010;485:60-64.

-53 Zhuang S, Yan Y, Daubert RA, Han J, Schnellmann RG: Erk promotes hydrogen peroxide-induced apoptosis through caspase- 3 activation and inhibition of akt in renal epithelial cells. Am J Physiol Renal Physiol 2007;292:F440-447.

54 Singh M, Sharma H, Singh N: Hydrogen peroxide induces apoptosis in hela cells through mitochondrial pathway. Mitochondrion 2007;7:367-373.

55 Mangiullo R, Gnoni A, Leone A, Gnoni GV, Papa S, Zanotti F: Structural and functional characterization of $\mathrm{f}(\mathrm{o}) \mathrm{f}(1)$-atp synthase on the extracellular surface of rat hepatocytes. Biochim Biophys Acta 2008;1777:1326-1335.

56 Piccoli C, Ria R, Scrima R, Cela O, D'Aprile A, Boffoli D, Falzetti F, Tabilio A, Capitanio N: Characterization of mitochondrial and extra-mitochondrial oxygen consuming reactions in human hematopoietic stem cells. Novel evidence of the occurrence of nad(p)h oxidase activity. J Biol Chem 2005;280:26467-26476.

57 Panfoli I, Calzia D, Bianchini P, Ravera S, Diaspro A, Candiano G, Bachi A, Monticone M, Aluigi MG, Barabino S, Calabria G, Rolando M, Tacchetti C, Morelli A, Pepe IM: Evidence for aerobic metabolism in retinal rod outer segment disks. Int J Biochem Cell Biol 2009;41:2555-2565.

58 Maiuri MC, Zalckvar E, Kimchi A, Kroemer G: Self-eating and self-killing: Crosstalk between autophagy and apoptosis. Nat Rev Mol Cell Biol 2007;8:741-752.

59 Wen X, Wu J, Wang F, Liu B, Huang C, Wei Y: Deconvoluting the role of reactive oxygen species and autophagy in human diseases. Free Radic Biol Med 2013;65:402-410.

-60 Kiffin R, Bandyopadhyay U, Cuervo AM: Oxidative stress and autophagy. Antioxid Redox Signal 2006;8:152162.

61 Zhang C, Yang L, Wang XB, Wang JS, Geng YD, Yang CS, Kong LY: Calyxin y induces hydrogen peroxidedependent autophagy and apoptosis via jnk activation in human non-small cell lung cancer nci-h460 cells. Cancer Lett 2013;340:51-62.

62 Fimia GM, Piacentini M: Regulation of autophagy in mammals and its interplay with apoptosis. Cell Mol Life Sci 2010;67:1581-1588.

63 Wu W, Wei W, Ablimit M, Ma Y, Fu T, Liu K, Peng J, Li Y, Hong H: Responses of two insect cell lines to starvation: Autophagy prevents them from undergoing apoptosis and necrosis, respectively. J Insect Physiol 2011;57:723-734.

64 Wang Q Chen Z, Diao X, Huang S: Induction of autophagy-dependent apoptosis by the survivin suppressant ym155 in prostate cancer cells. Cancer Lett 2011;302:29-36.

65 Lee SJ, Cho KS, Koh JY: Oxidative injury triggers autophagy in astrocytes: The role of endogenous zinc. Glia 2009;57:1351-1361.

-66 Martinez-Lopez N, Athonvarangkul D, Mishall P, Sahu S, Singh R: Autophagy proteins regulate erk phosphorylation. Nat Commun 2013;4:2799.

67 Cagnol S, Chambard JC: Erk and cell death: Mechanisms of erk-induced cell death--apoptosis, autophagy and senescence. FEBS J 2010;277:2-21.

-68 Sivaprasad U, Basu A: Inhibition of erk attenuates autophagy and potentiates tumour necrosis factor-alphainduced cell death in mcf-7 cells. J Cell Mol Med 2008;12:1265-1271.

69 Yang YH, Chen K, Li B, Chen JW, Zheng XF, Wang YR, Jiang SD, Jiang LS: Estradiol inhibits osteoblast apoptosis via promotion of autophagy through the er-erk-mtor pathway. Apoptosis 2013;18:1363-1375. 